\title{
Regional Perspective of Digitalization in BRICS ${ }^{1}$
}

\author{
A. Morozkina
}

Aleksandra Morozkina - PhD, Associate Professor, HSE University; Senior Research Fellow, Financial Research Institute of the Ministry of Finance of the Russian Federation; Russian Federation, Moscow, bldg. 2 , 17 Malaya Ordynka Ulitsa; E-mail: a.k.morozkina@gmail.com

\begin{abstract}
This article is aimed at evaluation of regional digital inequality in BRICS countries. Using the data for 2014-2018 on internet usage and access to fixed broadband author calculates inequality ratios, including coefficient of variation and Theil index. Also author analyzes rural/urban differences and their dynamics. On the base of this calculations author shows decrease of regional inequality in all five countries. Further analysis is devoted to national digitalization strategies, which are aimed at development of remote areas and bridging digital divide. Author shows that there are measures in each strategy aimed at bridging digital divide on all three levels (infrastructure, usage and results). In a final part of the article author suggests directions for cooperation in BRICS, including exchange of best practices in realization of national strategies, composition of best practices in integrated measures aimed at development of remote areas and joint financing using opportunities provided by the New Development Bank.
\end{abstract}

Key words: digital divide; digitalization; BRICS; regional divide; development of remote areas; internet access

For citation: Morozkina A. (2020) Regional Perspective of Digitalization in BRICS. International Organisations Research Journal, vol. 15, no 4, pp. 70-90 (in English). DOI: 10.17323/1996-7845-2020-04-04.

\section{Introduction}

Cooperation on the digital economy and promotion of the economic development of remote areas was declared a priority by Russia during its tenure as the chair of BRICS in 2020. Digitalization is the process of integrating information and telecommunications technologies (ICTs) into daily routines. It incorporates the following three aspects: creation of a digital infrastructure (including Internet access); development of users' digital literacy; and assurance of social advantages arising from the use of ICTs in day-to-day operations. This process carries a risk of rising inequality, particularly regional inequality, due to the economic inefficiency of digitalization in remote and rural areas, where high costs of infrastructure building are combined with low digital literacy rates and low demand for Internet services.

Reduction of digital inequality constitutes a sustainable development priority; for example, the number of fixed Internet broadband subscriptions and Internet users per 100 inhabitants serve as indicators for the achievement of United Nations Sustainable Development Goals 17.6 and 17.8. In the context of the fourth industrial revolution and acceleration of digitalization processes, the use of digital technologies serves as the premise for the possibility of participating in global value chains, and the gap in access to technologies may serve as an additional source of inequality between different countries and regions within countries, for example, between providers of intellectual capital and physical labour. Digital technologies have become particularly

${ }^{1}$ The editorial board received the article in August 2020. 
significant during the pandemic as prior efforts to ensure broader access to digital technologies has allowed all economic agents to make faster adjustments to their operations under the new circumstances.

All five BRICS members are actively implementing digitalization policies. Therefore, it is important to control potential risks associated with a rise in regional inequality. In order to exercise such control, we must perceive whether an increase in the application of digital technologies at the national level is accompanied by the lagging behind of least developed areas and higher inequality in access to technologies. Moreover, we need to understand how the outcomes of digitalization programmes correlate with wider access to ICTs in least developed regions.

This study analyzes and assesses regional inequality in Internet access in BRICS countries. The objective of the study is to trace the dynamics of regional inequality rates in BRICS countries and determine differences within the group. In order to achieve this objective, the national level of digitalization in BRICS countries was analyzed, and regional digitalization data for the five BRICS members was collected to assess the level of regional inequality for each country. The relevance of this research derives from the implementation of strategies that seek to bridge the digital divide in all BRICS countries and the need to monitor intermediary results.

The article begins with a review of research on the subject and demonstrates that the regional aspect of digitalization in BRICS states has been studied insufficiently. It then considers the main measures introduced by BRICS members with the purpose of decreasing inequality and analyzes differences in Internet access for BRICS members by region. It offers assessments of inequality dynamics as they pertain to Internet access by types of settlements and by regions within BRICS countries. The article concludes with recommendations for cooperation between BRICS members in the field of digitalization.

\section{Literature Review}

Sources on the subject have rather widely covered the issue of digital inequality; they have recognized both the infrastructural and the social aspect [Norris, 2001; Perfilieva, 2007; Song, 2020] and actively explored the effect of digitalization on economic indicators such as output, performance, employment, income and poverty [Hofman, Aravena, Aliaga, 2016; Jung, Lopez-Bazo, 2020; Katz, Callorda, 2018; Niebel, 2014]. One study [Hofman, Aravena, Aliaga, 2016] identifies two channels for affecting macroeconomic indicators: satisfaction of demand on digital products (devices and software) and an increase in efficiency, employment and investment in economic segments that use information technologies. Still, the effect on economic indicators varies depending on the use of different technologies (e.g. fixed and mobile communications), the difference in a country's level of development [Niebel, 2014] that expands their application, and the default level of technologies' development and their coverage [Katz, Callorda, 2018].

The overwhelming majority of sources use national-level indicators, even though they do not capture the evenness of digital technologies' coverage and may favour countries with a high degree of urbanization and with only large cities being connected to digital technologies [Lucendo-Monedero, 2019]. Assessments that use regional data remain rather fragmented, and they typically consider the situation in just one country. Studies that explored the effect of the geographic factor on digitalization levels in the U.S., Japan and Indonesia [Jung, Lopez-Bazo, 2020; Lucendo-Monedero, 2019] showed that this factor plays an important role in explaining the differences in levels of the digital divide, which is why the development of access to ICTs should prioritize the least developed, hard-to-reach and remote areas. 
A study on the use of ICTs in Chinese provinces [Song, Wang, Bergmann, 2020] analyzed data on access to digital technologies and their use by Chinese prefectures in 2016 and came to the conclusion that the digital divide exists at all three levels. Another study on Chinese provinces [Liu, Wang, 2019] showed that the implementation of the national plan for spreading broadband Internet facilitated an increase in Internet coverage in China in 2012-15 and, in most cases, promoted the alignment of provinces according to Internet accessibility and use. A study on Brazilian regions [Jung, Lopez-Bazo, 2020] established that in 2007-11 production efficiency depended on broadband Internet access in Brazil at the level of states, but the author also noted the unevenness of obtained results. As for Russia, the Analytical Center for the Government of the Russian Federation points out that regional idiosyncrasies constitute an important factor affecting the digitalization level of Russia's constituent entities and that "the problem often occurs because building communication networks in scarcely populated and remote areas is not economically feasible" [Analytical Center, 2019, p. 23]. A study by M.Yu. Arkhipova and V.P. Sirotin exposed a large divide in wired network technologies compared against "the digital gap in basic ICTs" [2019, p. 676]. In their study of access to ICTs in India, T. Agarwal and P.K. Panda [2018] used 2008-17 data to show an increase in inequality between states, despite faster access growth in less developed states. Another study on India [Bera, 2019] reported similar results based on 2006-16 state-level data and came to the conclusion that differences in digitalization drivers (infrastructure, human capital and provider competition) between states were rising along with an increase in accessibility of digital technologies in all states. It appears that, due to the lack of long-term records on digitalization levels in South Africa, there are no studies dedicated exclusively to the analysis of regional inequality in the field of digitalization, albeit it has been noted that such research is necessary [Bornman, 2015].

Differences in development levels of BRICS members' regions [Analytical Center, 2018] and their urban and rural areas allow for the assumption that the coverage and use of digital technologies are distributed unevenly in these countries. Wider Internet coverage in rural and remote areas may expand the range of opportunities available to their inhabitants and result in business development, performance improvement in agriculture and better access to healthcare and education [Deng, 2019; Jung, Lopez-Bazo, 2020; Lucendo-Monedero, 2019]. Numerous studies [Agarwal, Panda, 2018; Bera, 2019; Jung, Lopez-Bazo, 2020; Liu, Wang, 2019; Song, Wang, Bergmann, 2020] point out the importance of monitoring and overcoming the digital divide, particularly at the regional level, in BRICS countries. Still, there have been no attempts to assess regional inequality as it pertains to access to digital technologies in all five member countries.

Scholarly research also points out the importance of cooperation on digitalization between BRICS countries. For example, information and communications technologies were labelled a priority in science and technology cooperation between BRICS members [Sidorova, 2018; Sokolov et al., 2017] and cooperation on the development of global rules that would regulate the digital space [Ignatov, 2020; Tkachenko, 2018].

\section{Digitalization Programmes in BRICS Countries}

Bridging the digital divide is a priority for all BRICS members given its promise to decrease inequality. The first part of the Brazilian Digital Transformation Strategy is dedicated to increasing the accessibility of digital technologies and expanding broadband Internet coverage nationwide, including remote and isolated areas. In India, the expansion of mobile network coverage and development of broadband Internet infrastructure constitute two main directions of the Digital India programme. A more detailed action plan is presented in the National Digital Communi- 
cations Policy, which was adopted in 2018, and BharatNet - a programme for connecting rural areas to the national optical fibre network - which was implemented in 2012. In China, one of the priorities included in the 13th Five-Year Plan for 2016-20 stipulates the provision of access to broadband networks in remote mountainous areas, islands and reefs. In Russia, Internet access for small settlements is part of the Digital Economy national programme. In South Africa, the South Africa Connect strategy envisions an increase in broadband Internet accessibility and speed. Measures stipulated under these programmes target a decrease in the digital divide at all three levels (Table 1).

The most popular measure for spreading Internet access is infrastructure building, and it is included in the programme documents of all five countries. At the same time, national objectives on broadband Internet coverage and speed vary greatly by their outreach. Each country's specific objectives are provided in Appendix 1. At the second level, all five countries are implementing the same measure of connecting state agencies to the Internet. In addition, Russia and India stipulate measures that target higher digital literacy and, given the commitment to this objective and low digital literacy rates in other BRICS countries, Russia introduced the initiative to launch the BRICS Digital Literacy School [TPP RF, 2019] and exchange best practices in this area. Measures targeting the expansion of opportunities related to digital technologies, as well as measures stipulated at other levels, are predominantly related to the public sector. Indeed, the state plays a critical role not only in spreading Internet access but also in creating and using accessible Internet services and clear digital content for its population with low digital literacy. That is why digitalization of public services can both decrease related costs and create stimuli for the development of digital competences.

Table 1. Examples of Measures Aimed at Bridging the Digital Divide in National Digital Strategies of BRICS Countries

\begin{tabular}{|c|c|c|c|c|c|}
\hline Brazil & Russia & India & China & S. Africa & \\
\hline \multicolumn{6}{|c|}{ Level 1: Access } \\
\hline Infrastructure building & + & + & + & + & + \\
\hline $\begin{array}{l}\text { Decrease of costs for telecommunications } \\
\text { companies, which increase mobile internet } \\
\text { coverage (tax relief, decrease of licenses } \\
\text { costs) }\end{array}$ & + & & + & & \\
\hline $\begin{array}{l}\text { Usage of mixed financing sources } \\
\text { (PPP, special-purpose funds) }\end{array}$ & + & + & + & & \\
\hline $\begin{array}{l}\text { Standardization of costs and time } \\
\text { for infrastructure building }\end{array}$ & & & + & & \\
\hline $\begin{array}{l}\text { Joint usage of existing infrastructure by } \\
\text { telecommunications companies }\end{array}$ & & + & + & & \\
\hline \multicolumn{6}{|c|}{ Level 2: Usage } \\
\hline $\begin{array}{l}\text { Connection of public agencies, including } \\
\text { educational, in rural and urban areas, } \\
\text { to broadband internet }\end{array}$ & + & + & + & + & + \\
\hline Increase of digital literacy & + & + & + & & \\
\hline $\begin{array}{l}\text { Increase of qualification of public servants } \\
\text { in digital sphere }\end{array}$ & & & & & + \\
\hline
\end{tabular}




\begin{tabular}{|c|c|c|c|c|c|}
\hline Brazil & Russia & India & China & S. Africa & \\
\hline \multicolumn{6}{|c|}{ Level 3: Opportunities } \\
\hline $\begin{array}{l}\text { Digitalization of public services, } \\
\text { development of e-government, provision of } \\
\text { information to the public }\end{array}$ & + & + & + & + & + \\
\hline $\begin{array}{l}\text { Development of national vacancies } \\
\text { database }\end{array}$ & & + & & & \\
\hline $\begin{array}{l}\text { Development of biometric identification } \\
\text { system }\end{array}$ & + & + & + & + & + \\
\hline
\end{tabular}

Source: [Digital India, n. d.; Government of Brazil, 2018; Government of India, 2018; Government of the People's Republic of China, 2016; Government of the Russian Federation, 2018; Government of South Africa, 2013].

\section{Analysis of the Digital Divide in BRICS Countries}

BRICS countries have been successful in spreading digital technologies and decreasing the digital divide, even though their accessibility varies between members. The digital divide can be defined as "the gap between individuals, households, businesses and geographic areas with regard both to their opportunities to access information and communication technologies and to their use of the Internet for a wide variety of activities" [OECD, 2001, p. 5]. In order to assess the divide, it is necessary to account not only for the level of digital infrastructure development but also the population's opportunities for accessing new technologies, as well as the existence of advantages in the use of digital technologies, including a developed market of e-commerce and electronic public services. With the development of digital infrastructure, the so-called digital divide of the second level, that is, "capabilities for harnessing digital data and frontier technologies" [UNCTAD, 2019, p. 16], comes to the fore. But BRICS countries must still pay attention to the issue of developing physical infrastructure, even though China has become a leader in development of the digital economy alongside the U.S. [UNCTAD, 2019].

There are rather extensive data on BRICS members at the national level, which allows for an assessment of the degree of the digital divide compared to economies with the most developed digital segments. Singapore and Sweden were selected for comparison because they are included in the top five of most rankings. For example, both countries are in the top five of the Networked Readiness Index [Dutta, Lanvin, 2019] and Global Competitiveness Report - 3d Pillar [WEF, 2019]; Singapore is in the top five of the Mobile Connectivity Index [GSMA, 2019] while Sweden is in the top five of the Inclusive Internet Index [2020].

BRICS countries are heterogeneous by the level of their digital divide. For example, in certain aspects (number of fixed broadband subscriptions, average download speed through mobile broadband access and number of active social media users) China is outperforming even developed countries. In some areas (e.g. international bandwidth, share of Internet users and price of fixed Internet subscriptions), Russia also demonstrates a rather high level compared to other countries, whereas the majority of India's and South Africa's indicators are at an extremely low level even when compared to other developing countries.

It is impossible to perform a detailed analysis at the regional level for all five BRICS members due to data fragmentation, so for this analysis two main indicators were selected - Internet use by the population and access to fixed broadband Internet - because they, out of all available indices, allow for the most comprehensive assessment of the presence or absence of the digital divide. The first indicator reflects opportunities for using digital technologies available to a region's population, and the second indicator attests to the accessibility of relevant infrastructure. 
Table 2. Digital Divide Indicators on Three Levels: BRICS, Singapore and Sweden

\begin{tabular}{|c|c|c|c|c|c|c|c|}
\hline Brazil & China & India & Russia & S. Africa & Singapore & Sweden & \\
\hline \multicolumn{8}{|c|}{ Access } \\
\hline $\begin{array}{l}\text { Fixed broadband subscriptions } \\
\text { (per } 100 \text { inhabitants) }\end{array}$ & 13.8 & 29.2 & 1.3 & 21.7 & 2.5 & 28.0 & 39.8 \\
\hline $\begin{array}{l}\text { Active mobile-broadband } \\
\text { subscriptions (per } 100 \\
\text { inhabitants) }\end{array}$ & 88.1 & 95.4 & 37.5 & 87.3 & 76.0 & 145.7 & 123.0 \\
\hline 3G Coverage (\% pop.) & 95.5 & 99.4 & 94.0 & 78.0 & 99.5 & 100.0 & 100.0 \\
\hline $\begin{array}{l}\text { Download speed, fixed bb } \\
\text { (Mbps) }\end{array}$ & 47.8 & 101.3 & 38.0 & 60.7 & 27.9 & 193.2 & 127.9 \\
\hline $\begin{array}{l}\text { Download speed, mobile bb } \\
\text { (Mbps) }\end{array}$ & 23.8 & 58.4 & 11.2 & 20.4 & 34.9 & 53.6 & 47.3 \\
\hline $\begin{array}{l}\text { International Internet } \\
\text { bandwidth (bit/s) }\end{array}$ & 29.2 & 27.7 & 25.9 & 68.0 & 10.5 & 954.3 & 67.7 \\
\hline \multicolumn{8}{|c|}{ Usage } \\
\hline Internet users (\% pop.) & 69.8 & 52.9 & 37.0 & 82.4 & 61.8 & 88.2 & 92.1 \\
\hline $\begin{array}{l}\text { Use of virtual social networks } \\
\text { (\% pop.) }\end{array}$ & 66.0 & 71.0 & 23.0 & 49.0 & 40.0 & 79.0 & 72.0 \\
\hline Internet shopping (\% pop.) & 24.0 & 39.0 & 2.9 & 26.0 & 7.9 & 63.0 & 77.0 \\
\hline Adult literacy (\% pop.) & 93.2 & 96.8 & 74.4 & 99.7 & 87.0 & 97.3 & 99.0 \\
\hline $\begin{array}{l}\text { Tax to cost of ownership of } \\
\text { mobile phone (\%) }\end{array}$ & 33.2 & 13.0 & 23.3 & 18.0 & 14.0 & 7.0 & 25.0 \\
\hline $\begin{array}{l}\text { Fixed BB subscription charge } \\
\text { (\% GDP per capita) }\end{array}$ & 2.4 & 2.2 & 4.5 & 0.5 & 2.7 & 0.8 & 1.0 \\
\hline \multicolumn{8}{|c|}{ Opportunities } \\
\hline OSI (Online Service Index) & 0.9 & 0.9 & 1.0 & 0.9 & 0.8 & 1.0 & 0.9 \\
\hline Firms with website ( $\%$ of firms) & 54.0 & 66.1 & 48.9 & 64.6 & 36.0 & - & 92.4 \\
\hline $\begin{array}{l}\text { Number of active mobile } \\
\text { applications developed per } \\
\text { person }\end{array}$ & 73.4 & 67.5 & 61.9 & 75.8 & 67.8 & 97.2 & 88.2 \\
\hline $\begin{array}{l}\text { Value added of ICT sector (\% } \\
\text { GDP) }\end{array}$ & 2.7 & 4.8 & 5.1 & 2.1 & 2.1 & 9.0 & 5.6 \\
\hline
\end{tabular}

Source: [Dutta, Lanvin, 2019; GSMA, 2019; Inclusive Internet Index, 2020; ITU, n. d.; UN, 2018; UNCTAD, 2019; UNESCO UIS, n. d.].

Analysis of spatial inequality in Internet access by region for BRICS countries is based on their national statistics. Data on Internet use in Brazil come from polls taken by Tecnologia Informação e Comunicação da Pesquisa Nacional de Amostra de Domicílios (TIC PNAD) [IBEG, n. d.] in 2005, 2008, 2011 and 2013-17, but disaggregation by state is available only for 2005, 2008, 2014, 2016 and 2017. Assessment of fixed access to broadband Internet relies on data from the Brazilian Association of Telecommunications (Telebrasil) database [n. d.]. Information on India is taken from annual India Telecoms Reports, which have been published 
by the Ministry of Communications of India [Government of India, n. d.] since 2004, but data breakdown by state has been provided only since 2014. For China, data on access to information technologies have been provided annually since 2011 in the China Statistical Yearbook published by the National Bureau of Statistics of China [n. d.]. For Russia, data on Internet use are collected under the federal statistical sampling on the use of information technologies and information and telecommunications networks published by the Federal State Statistics Service [n. d.] since 2013. Information on fixed broadband Internet access has been included in statistics published by the Ministry of Digital Development, Communications and Mass Media [n. d.] since 2011. For South Africa, data on the use of digital technologies with breakdown by province has been published since 2015 in the annual report of the Independent Communications Authority of South Africa [ICASA, 2019].

In order to compare data on Internet use at the regional level in BRICS countries, the constituent entities (states, provinces, etc.) of each country were split into four groups - financial and economic centres, developed, medium developed and less developed - based on the classification suggested by the Analytical Center for the Government of the Russian Federation [Analytical Center, 2017; 2018].

As expected, analysis of data on Internet use at the regional level in BRICS countries shows (Table 3) that, typically, inhabitants of more developed regions use the Internet more actively (except for Russia), and the share of population using the Internet is increasing for all groups of regions. In Russia, the absence of a clear correlation between the development level of a constituent entity and Internet use is related to geographic idiosyncrasies. Less developed areas may have sparse highly urbanized populations (e.g. Magadan Oblast) and, consequently, better opportunities for accessing digital technologies. At the same time, some more developed regions (Vologda Oblast, Pskov Oblast and Tambov Oblast) have a large number of small settlements with fewer than 100 inhabitants, which renders the development of Internet access economically unfeasible for telecommunications providers. A similar situation can be observed when comparing access levels in medium developed and developed regions of South Africa. According to the classification of the Analytical Center, KwaZulu-Natal province is a developed region due to its large share of the processing industry in the implicit gross regional product (GRP) by purchasing power parity (PPP), but the level of Internet use on its territory (55\%) is lower than in the medium developed provinces of Mpumalanga (63\%) and Free State (61\%).

Table 3. Share of Population Using Internet, Breakdown by Regions of BRICS Countries, 2014 and Latest Available Data

\begin{tabular}{|l|c|c|c|c|c|c|c|c|c|c|}
\hline \multirow{2}{*}{} & \multicolumn{2}{|c|}{ Brazil } & \multicolumn{2}{c|}{ India } & \multicolumn{2}{c|}{ China } & \multicolumn{2}{c|}{ Russia } & \multicolumn{2}{c|}{ S. Africa } \\
\cline { 2 - 11 } & $\mathbf{2 0 1 4}$ & $\mathbf{2 0 1 7}$ & $\mathbf{2 0 1 4}$ & $\mathbf{2 0 1 8}$ & $\mathbf{2 0 1 4}$ & $\mathbf{2 0 1 6}$ & $\mathbf{2 0 1 4}$ & $\mathbf{2 0 1 8}$ & $\mathbf{2 0 1 5}$ & $\mathbf{2 0 1 7}$ \\
\hline $\begin{array}{l}\text { Financial } \\
\text { and economic } \\
\text { centres }\end{array}$ & 67.8 & 80.9 & 54.8 & 96.2 & 72.4 & 75.9 & 79.4 & 87.7 & 64.5 & 72.4 \\
\hline Developed & 55.9 & 73.1 & 23.3 & 45.7 & 53.9 & 58.6 & 74.3 & 80.6 & 42.3 & 54.8 \\
\hline Medium-developed & 44.2 & 62.9 & 18.9 & 35.6 & 44.5 & 49.8 & 70.3 & 78.7 & 50.8 & 59.1 \\
\hline Less developed & 40.9 & 56.6 & 14.5 & 28.9 & 37.5 & 44.3 & 68.5 & 82.7 & 42.7 & 47.7 \\
\hline Total & 54.9 & 69.8 & 20.0 & 37.0 & 47.4 & 52.9 & 64.9 & 82.4 & 48.7 & 61.8 \\
\hline
\end{tabular}

Source: Author's calculations. 
Analysis of the accessibility of fixed broadband access (Table 4) foregrounds the dependence of accessibility on a region's development level. Table 4 shows that the National Broadband Development Plan before 2020, which specifically emphasizes the need for a balanced development of regions and an even access to high-speed Internet, has had a rather strong positive effect. We can see that China's less developed provinces were the most successful in increasing access level in 2014-18.

Table 4. Share of Population Using Fixed Broadband Internet,

Breakdown by Regions of BRICS Countries, 2014 and Latest Available Data

\begin{tabular}{|l|c|c|c|c|c|c|c|c|}
\hline \multirow{2}{*}{} & \multicolumn{2}{|c|}{ Brazil } & \multicolumn{2}{c|}{ India } & \multicolumn{2}{c|}{ China } & \multicolumn{2}{c|}{ Russia } \\
\cline { 2 - 9 } & $\mathbf{2 0 1 4}$ & $\mathbf{2 0 1 7}$ & $\mathbf{2 0 1 5}$ & $\mathbf{2 0 1 8}$ & $\mathbf{2 0 1 4}$ & $\mathbf{2 0 1 8}$ & $\mathbf{2 0 1 4}$ & $\mathbf{2 0 1 8}$ \\
\hline $\begin{array}{l}\text { Financial and economic } \\
\text { centres }\end{array}$ & 19.2 & 21.4 & 3.7 & 5.1 & 23.2 & 30.8 & 18.5 & 24.3 \\
\hline Developed & 12.1 & 14.9 & 1.6 & 1.8 & 13.3 & 31.4 & 17.4 & 22.0 \\
\hline Medium-developed & 5.1 & 6.9 & 0.7 & 0.8 & 8.9 & 26.6 & 14.5 & 19.8 \\
\hline Less developed & 5.0 & 6.5 & 0.5 & 0.6 & 7.0 & 25.7 & 7.7 & 10.4 \\
\hline Total & 11.8 & 13.8 & 1.2 & 1.3 & 14.7 & 29.2 & 17.0 & 21.7 \\
\hline
\end{tabular}

Source: Author's calculations.

\section{Assessment of BRICS Countries' Regional Inequality in Internet Access}

\section{Methodology}

Dynamics of the regional digital divide in BRICS countries are assessed based on spatial inequality indicators for 2014-18. Sources on the subject suggest several different spatial inequality indicators [Luk'ianova, 2007], the most prominent being: absolute range of variability, relative range of variability, variation ratio and the Theil index. The interpretation and data record of the aforementioned indices for assessing the level of digitalization development are provided below.

Absolute range of variability is calculated as the difference between the maximum and minimum values of the variation sampling:

$$
R a=\operatorname{Max}(y)-\operatorname{Min}(y),
$$

where $y=\left(y_{1}, y_{2}, \ldots y_{\mathrm{n}}\right)$ stands for the vector of the shares of population with Internet access in $n$ regions/constituent entities of a country.

Experiential studies rarely use this indicator because the minimum and maximum values often prove to be outlying cases obtained as a result of observation errors, and their inclusion would skew the findings of a study. Nevertheless, when assessing differences in the level of digitalization, it is this indicator that can rather adequately reflect the differences in accessibility of technologies between the most and least developed regions. Moreover, only this indicator can be used to assess inequality dynamics between urban and rural areas because there are only two parameters (urban/rural) for each country at each moment in time.

Relative range of variability is calculated as the proportion of the difference between the maximum and minimum values to the mean value: 


$$
R_{r}=\frac{\operatorname{Max}(y)-\operatorname{Min}(y)}{\bar{y}},
$$

where $y=\left(y_{1}, y_{2}, \ldots y_{\mathrm{n}}\right)$ stands for the vector of the shares of population with Internet access in $n$ regions/constituent entities of a country, $\bar{y}$ stands for the average share of population with Internet access.

This indicator's weaknesses are similar to the drawbacks associated with the absolute range of variability.

Variation ratio is defined as the proportion of the standard deviation to the mean value and assesses the range of variation from the mean level. The ratio increases with the rise in differences between territories.

$$
V=\frac{\sqrt{\left(y_{i}-\bar{y}\right)^{2}}}{\bar{y}},
$$

where $y_{i}$ stands for the share of population with Internet access in a region $i, \bar{y}$ stands for the average share of population with Internet access.

The ratio is highly sensitive to outlying cases and strong deviations from the mean; the weight of small deviations decreases, and the weight of large deviations increases in the total sum of deviations.

The Theil index constitutes a special case of the so-called "generalized entropy indices" and is calculated using the following formula:

$$
T=\frac{1}{n} \sum_{i=1}^{n}\left(\frac{y_{i}}{\bar{y}} \ln \frac{y_{i}}{\bar{y}}\right)
$$

where $y_{i}$ stands for the share of population with Internet access in a region $i, \bar{y}$ stands for the average share of population with Internet access; $n$ stands for the number of regions.

The Theil index assigns the same weight to observations over the entire distribution scale and is equally sensitive to changes in the level of access over the entire distribution scale, which is why it may be argued that it is best suited for the purposes of this study.

\section{Results}

The development divide between urban and rural areas is common knowledge in the scholarly literature, but it takes on special meaning in the context of digitalization. First, rural areas are less densely populated and, therefore, require a much more intricate infrastructure, both for fixed and mobile access. Second, the rural population is typically less educated (this applies to its digital literacy as well), so it may not use digital infrastructure even if it exists, which makes the development of access less feasible for communications providers. Third, weak transport infrastructure in rural areas discourages the development of various elements of the digital economy, including e-commerce, due to high shipping costs and inefficiency of opening pickup points.

All BRICS members exhibit lower Internet use in rural areas compared to urban areas (Table 5), whereas the national level depends, to a great extent, on the share of the rural population, which is the highest in India (as of 2018, 66\% of the population lived in rural areas). In India and China, differences between urban and rural territories increased in 2014-18; in Brazil, Russia and South Africa, they dropped. In other words, from the urban/rural perspective, inequality decreased in Brazil, Russia and South Africa and rose in India and China. 
Table 5. Share of Population Using Internet in Urban and Rural Areas, BRICS, 2014, 2018

\begin{tabular}{|l|c|c|c|c|c|c|c|c|}
\hline & \multicolumn{4}{|c|}{$\mathbf{2 0 1 4}$} & \multicolumn{4}{|c|}{2018} \\
\hline Urban & Rural & $\begin{array}{c}\text { Absolute } \\
\text { Range of } \\
\text { Variability }\end{array}$ & $\begin{array}{c}\text { National } \\
\text { Level }\end{array}$ & Urban & Rural & $\begin{array}{c}\text { Absolute } \\
\text { Range of } \\
\text { Variability }\end{array}$ & $\begin{array}{c}\text { National } \\
\text { Level }\end{array}$ \\
\hline Brazil & 72 & 32 & 40 & $\mathbf{5 5}$ & 80 & 59 & 21 & $\mathbf{7 0}$ \\
\hline India & 42 & 11 & 31 & $\mathbf{2 0}$ & 76 & 16 & 59 & $\mathbf{3 7}$ \\
\hline China & 63 & 29 & 34 & $\mathbf{4 7}$ & 75 & 35 & 40 & $\mathbf{5 3}$ \\
\hline Russia & 70 & 51 & 19 & $\mathbf{6 5}$ & 82 & 71 & 11 & $\mathbf{8 2}$ \\
\hline S. Africa* & 51 & 34 & 17 & $\mathbf{4 9}$ & 62 & 40 & 22 & $\mathbf{6 2}$ \\
\hline
\end{tabular}

Source: Author's calculations based on Federal State Statistic Service [n. d.], Government of India [n. d], IBGE [n. d.], ICASA [2019] and National Bureau of Statistics of China [n. d.].

*Note: For South Africa data are for 2015 and 2017 respectively.

If the regional aspect of inequality is considered, all BRICS countries exhibit the same tendency toward a decrease in the level of inequality, as manifested in the dynamics of three out of four indicators (with the exception of the absolute range of variability, which increased in India, Russia and South Africa). For India, the increase can be explained by the prominent role of outlying cases which factored into the calculation of this indicator: the share of mobile and fixed Internet subscriptions in New Delhi is almost two times higher than in the state of Himachal Pradesh, which is ranked next. In Russia, the increase in the absolute range of variability in 2018 compared to 2014 is tied to the instability of this indicator ( 26 in 2014, 28.5 in 2015, 23.4 in 2016, 25.9 in 2017 and 27.5 in 2018), which, in turn, can be explained by close values for different regions and changes in their positions in the ranking.

Table 6. Inequality Indicators for the Share of Population Using Internet, by Regions of BRICS

\begin{tabular}{|l|c|c|c|c|c|c|c|c|c|c|}
\hline & \multicolumn{2}{|c|}{ Brazil } & \multicolumn{2}{c|}{ India } & \multicolumn{2}{c|}{ China } & \multicolumn{2}{c|}{ Russia } & \multicolumn{2}{c|}{ S. Africa } \\
\cline { 2 - 12 } & $\mathbf{2 0 1 4}$ & $\mathbf{2 0 1 7}$ & $\mathbf{2 0 1 4}$ & $\mathbf{2 0 1 8}$ & $\mathbf{2 0 1 4}$ & $\mathbf{2 0 1 6}$ & $\mathbf{2 0 1 4}$ & $\mathbf{2 0 1 8}$ & $\mathbf{2 0 1 5}$ & $\mathbf{2 0 1 7}$ \\
\hline $\begin{array}{l}\text { Absolute range } \\
\text { of variability }\end{array}$ & 55 & 37 & 81 & 146 & 41 & 38 & 26 & 28 & 26 & 30 \\
\hline $\begin{array}{l}\text { Relative range } \\
\text { of variability }\end{array}$ & 1.11 & 0.56 & 3.82 & 3.58 & 0.89 & 0.72 & 0.36 & 0.34 & 0.52 & 0.51 \\
\hline Variation ratio & 0.233 & 0.138 & 0.690 & 0.687 & 0.247 & 0.190 & 0.079 & 0.071 & 0.176 & 0.160 \\
\hline The Theil index & 0.028 & 0.009 & 0.170 & 0.168 & 0.03 & 0.02 & 0.003 & 0.002 & 0.013 & 0.011 \\
\hline
\end{tabular}

Source: Author's calculations.

The lowest level of interregional divide in Internet use is observed in Russia, followed by Brazil, which achieved a dramatic decrease in the level of interregional inequality over the reporting period, possibly due to pursuing an active policy on digitalization of agriculture and rural areas.

As for infrastructure building (providing access to fixed broadband Internet), the situation is similar in all countries but India, where the level of inequality between states shows a signifi- 
cant increase over the reporting period (Table 7). This can be attributed to India emphasizing the development of mobile Internet, which, according to the International Telecommunication Union [ITU, 2019], constitutes an efficient strategy in developing countries because the development of mobile Internet at a lower level of economic development has a larger effect on the national gross domestic product (GDP). Research indicates that a $10 \%$ increase in mobile broadband Internet coverage results in a 1.8\% GDP increase in middle-income countries, whereas the expansion of fixed broadband Internet coverage accounts for only a $0.5 \%$ increase in GDP [ITU, 2019, p. 2].

Table 7. Inequality Indicators for the Share of Population Subscribed for Fixed Broadband Internet, by Regions of BRICS

\begin{tabular}{|l|c|c|c|c|c|c|c|c|}
\hline \multirow{2}{*}{} & \multicolumn{2}{|c|}{ Brazil } & \multicolumn{2}{c|}{ India } & \multicolumn{2}{c|}{ China } & \multicolumn{2}{c|}{ Russia } \\
\cline { 2 - 9 } & $\mathbf{2 0 1 4}$ & $\mathbf{2 0 1 7}$ & $\mathbf{2 0 1 5}$ & $\mathbf{2 0 1 8}$ & $\mathbf{2 0 1 4}$ & $\mathbf{2 0 1 8}$ & $\mathbf{2 0 1 4}$ & $\mathbf{2 0 1 8}$ \\
\hline Absolute range of variability & 18 & 19 & 6 & 9 & 17 & 26 & 31 & 35 \\
\hline Relative range of variability & 2.10 & 1.80 & 5.28 & 6.60 & 1.17 & 0.91 & 1.91 & 1.85 \\
\hline Variation ratio & 0.60 & 0.52 & 1.14 & 1.31 & 0.32 & 0.21 & 0.40 & 0.34 \\
\hline The Theil index & 0.16 & 0.12 & 0.47 & 0.55 & 0.05 & 0.02 & 0.10 & 0.07 \\
\hline
\end{tabular}

Source: Author's calculations.

Thus, the results of this analysis of the digital divide between rural and urban areas, as well as between regions of BRICS countries, allow for the conclusion that interregional inequality decreased over 2014-18. These results conform to the findings obtained in a study on China [Liu, Wang, 2019] but do not support conclusions for India [Bera, 2019; Agarwal, 2018]. This discrepancy may be related to several factors, the main one being the time period under consideration. First, the aforementioned studies stop at 2016, whereas major programmes seeking to decrease digital inequality in India were launched in 2012 (BharatNet programme for connecting rural areas to the national optical fibre network) and 2015 (Digital India); de facto core measures were taken toward the end of the studied period, which could affect obtained results. This study covers the period when major programmes for decreasing digital inequality were already in place. It is also worth noting that India, unlike other countries, exhibited an insignificant decrease in inequality, so the rise in inequality prior to the implementation of special programmes could indeed affect final results. Second, the previous studies use standard deviation to measure inequality, which assigns considerable weight to outlying cases in the top part of the distribution, which, given a significant deviation for Delhi, may significantly affect obtained results. In this study, results are more stable because several indicators were simultaneously applied in order to assess inequality.

\section{Conclusions and Potential Areas of Cooperation}

The importance of digital technologies and digitalization has been emphasized at all BRICS meetings, but cooperation in this area has been developing particularly actively since 2015, when Russia chaired BRICS. At the 2015 Ufa summit, quite a bit of attention was dedicated to potential cooperation on the development of digital infrastructure. The Ufa Declaration welcomed the inclusion of issues related to the development of digital technologies - providing the poorest population with access to mobile Internet - into the development agenda [BRICS, 
2015a]. The Physical Connectivity section of the Strategy for BRICS Economic Partnership identified fostering the development of transportation and communication infrastructure as a priority area of cooperation [BRICS, 2015b]. In addition, BRICS ICT ministers held their first meeting, and the BRICS Working Group on ICT Cooperation was created. Following that, the Goa Declaration, which was adopted in 2016 at a BRICS summit hosted by India, pointed to the need to exchange experiences among BRICS countries in order to bridge the digital divide, in particular by enhancing access to e-commerce [BRICS, 2016]. The issue of cooperation on digital technologies was also discussed in Johannesburg in 2018. Summit participants approved the initiative on the establishment of the Partnership on New Industrial Revolution (PartNIR), which, among other things, seeks to achieve an increase in inclusiveness [BRICS, 2018]. Throughout 2019, the PartNIR Advisory Group worked out the details and plan of action, which were approved in September 2020. Moreover, the 5th BRICS ICT Ministers Meeting was held in 2019. Its participants established an increase in connectivity and access to digital technologies as one of their priorities because connectivity and access to digital technologies serve as key enablers of the digital economy, inclusive growth and sustainable development [BRICS, 2019]. In 2020, cooperation on digital technologies and development of remote areas was declared a priority during Russia's tenure as BRICS chair [BRICS-Russia, 2020].

This study shows that all BRICS members have achieved certain success in decreasing internal inequality in accessibility and use of digital technologies, but countries' levels still vary. That is why interaction on overcoming the digital divide may start with exchanging experiences in the development of national strategies and measures for their implementation, as well as the introduction of amendments based on international practices. Apart from BRICS countries, this experience can be used by other developing countries, especially those that have not yet adopted national strategies on increasing accessibility of digital technologies.

The second potential area of cooperation may be to compile best practices and experiences in the implementation of specific projects on digitalization of remote areas, including the delineation of the most efficient technologies and approaches to bridging the digital divide. Since the development of digital technologies' accessibility in remote and rural areas requires an integrated approach that would combine the development of the digital economy as a whole with an increase in demand on mobile services, it is extremely important to exchange experiences in combining various practices with proven efficiency.

The third area is related to utilizing the potential for joint financing of projects on economic development and integration of remote areas, including using the New Development Bank as a source of funding. Indeed, the Bank's mission is to support infrastructure building and sustainable development efforts, but the current list of approved and proposed projects does not feature any digitalization initiatives, even though some related measures are embedded in certain projects supported by the Bank. For example, the Pará Sustainable Municipalities Project intends to extend the existing fibre optic cable by $1,000 \mathrm{~km}$ and provide Internet connectivity to 29 municipalities [NDB, n. d., a], and the Shengzhou Urban and Rural Integrated Water Supply and Sanitation Project stipulates measures for implementing smart water management systems. At the same time, the Bank, based on its mission, has the potential to expand its engagement in issues related to decreasing the digital divide in BRICS countries.

Thus, BRICS countries have a rather high potential for cooperation in bridging the digital divide. By unlocking this potential, they can facilitate sustainable and inclusive development of all five BRICS members. 


\section{References}

Agarwal T., Panda P.K. (2018) Pattern of Digital Divide and Convergence in Access to ICT Facilities Among the Indian States. Journal of Infrastructure Development, vol. 10, no 1-2, pp. 37-51. Available at: https://doi. org/10.1177\%2F0974930618809171.

Analytical Center. (2017) Dinamika promyshlennogo proizvodstva: regional'nye razlichiya [Dynamics of Industrial Production: Regional Differences]. Byulleten' o tekushchih tendenciyah rossijskoj ekonomiki [Newsletter on Current Trends in the Russian Economy], no 27. Available at: https://ac.gov.ru/archive/files/ publication/a/13824.pdf (accessed 25 March 2020) (in Russian).

Analytical Center. (2018) Strany BRIKS: klassifikaciya regionov [BRICS: Classification of Regions]. Byulleten' o tekushchih tendenciyah mirovoj ekonomiki [Newsletter on Current Trends in the Russian Economy], no 34. Available at: https://ac.gov.ru/archive/files/publication/a/17357.pdf (accessed 25 March 2020) (in Russian).

Analytical Center. (2019) Bar'ery v razvitii cifrovoj ekonomiki v sub'ektah Rossijskoj Federacii [Barriers to the Development of the Digital Economy in Regions of the Russian Federation]. Analiticheskij centr pri pravitel'stve Rossijskoj Federacii [Analytical Center of the Government of the Russian Federation]. Available at: https:// ac.gov.ru/archive/files/publication/a/25838.pdf (accessed 25 March 2020) (in Russian).

Arkhipova M.Yu, Sirotin V.P. (2019) Regional'nyye aspekty razvitiya informatsionno-kommunikatsionnykh i tsifrovykh tekhnologiy v Rossii [Development of Digital Technologies in Russia: Regional Aspects]. Ekonomika regiona [Economy of Region], vol. 15, no 3, pp. 670-83. Available at: https://doi.org/10.17059/2019-3-4 (in Russian).

Bera S. (2019) Club Convergence and Drivers of Digitalization Across Indian States. Telecommunications Policy, vol. 43, no 8, pp. 1-17. Available at: https://doi.org/10.1016/j.telpol.2019.04.006.

Bornman E. (2016) Information Society and Digital Divide in South Africa: Results of Longitudinal Surveys. Information, Communication \& Society, vol. 19, no 2, pp. 264-78. Available at: https://doi.org/10.1080/136911 8X.2015.1065285.

Brazilian Association of Telecommunications (Telebrasil). (n. d.) Database. Available at: http://www.telebrasil. org.br/panorama-do-setor/consulta-a-base-de-dados (accessed 4 November 2020).

Brazilian Institute of Geography and Statistics (IBGE). (n. d.) National Household Sample Survey: PNAD. Available at: https://www.ibge.gov.br/en/statistics/social/population/18079-brazil-volume-pnad1.html? $=\& \mathrm{t}=\mathrm{O}-$ que-e (accessed 4 November 2020).

BRICS. (2015a) Ufa Declaration. Ufa, 9 July. Available at: http://www.brics.utoronto.ca/docs/150709-ufadeclaration_en.html (accessed 26 July 2020).

BRICS. (2015b) The Strategy for BRICS Economic Partnership. Available at: http://www.brics.utoronto.ca/ docs/150709-partnership-strategy-en.html (accessed 26 July 2020).

BRICS. (2016) Goa Declaration. Goa, 16 October. Available at: http://www.brics.utoronto.ca/docs/161016goa.html (accessed 26 July 2020).

BRICS. (2018) Johannesburg Declaration. Johannesburg, 25-27 July. Available at: http://www.brics.utoronto. ca/docs/180726-JOHANNESBURG_DECLARATION-26_JULY_2018_as_at_07h11.pdf (accessed 26 July 2020).

BRICS. (2019) Declaration of the 5th BRICS Communications Ministers Meeting. Brasilia, 14 August. Available at: http://www.brics.utoronto.ca/docs/190814-communications.html (accessed 26 July 2020).

BRICS-Russia. (2020) Priorities of the Russian Federation's BRICS Presidency. Available at: https://eng.bricsrussia2020.ru/russia_in_brics/20191226/1469/Priorities-for-the-Russian-Federations-presidency-of-BRICS. html (accessed 4 November 2020).

Deng X., Xu D., Zeng M., Qi Y. (2019) Does Internet Use Help Reduce Rural Cropland Abandonment? Evidence From China. Land Use Policy, vol. 89, pp. 1-11. Available at: https://doi.org/10.1016/j.landusepol.2019.104243.

Digital India. (n. d.) Vision and Vision Areas. Available at: https://digitalindia.gov.in/content/vision-and-vision-areas (accessed 4 November 2020). 
Dutta S., Lanvin B. (eds) (2019) The Network Readiness Index 2019: Towards a Future-Ready Society. Portulans Institute Insight Report. Available at: https://networkreadinessindex.org/wp-content/uploads/2019/12/TheNetwork-Readiness-Index-2019_Full_draft-V2.pdf (accessed 25 March 2020).

Federal State Statistics Service (n. d.). Available at: https://rosstat.gov.ru/free_doc/new_site/business/it/fed_ nabl-croc/index.html (accessed 4 November) (in Russian).

Government of Brazil. (2018) Brazil Digital Transformation Strategy. Available at: https://www.gov.br/mcti/ pt-br/centrais-de-conteudo/comunicados-mcti/estrategia-digital-brasileira/estrategiadigital.pdf (accessed 25 March 2020).

Government of India. (2018) National Digital Communications Policy. Available at: https://dot.gov.in/sites/default/files/EnglishPolicy-NDCP.pdf (accessed 25 March 2020).

Government of India. (n. d.) Network Status. Department of Telecommunications. Available at: https://dot.gov. in/network-status (accessed 4 November 2020).

Government of South Africa. (2013) South Africa Connect. Available at: https://www.gov.za/sites/default/files/ gcis_document/201409/37119gon953.pdf (accessed 25 March 2020).

Government of the People's Republic of China. (2016) The 13th Five-Year Plan for Economic and Social Development of the People's Republic of China. Available at: https://en.ndrc.gov.cn/newsrelease_8232/201612/ P020191101481868235378.pdf (accessed 25 March 2020).

Government of the Russian Federation. (2018) Pasport nacional'noj programmy "Cifrovaya ekonomika Rossijskoj Federacii" [Passport of the National Programme "Digital Economy of the Russian Federation"]. Available at: https://digital.ac.gov.ru/upload/iblock/89d/FP_Informacionnaya_infrastruktura_26_12_2019.docx (accessed 25 March 2020).

GSMA. (2019) State of Mobile Connectivity Report”. Available at: https://www.gsma.com/mobilefordevelopment/resources/the-state-of-mobile-internet-connectivity-report-2019/ (accessed 25 March 2020).

Hofman A., Aravena C., Aliaga V. (2016) Information and Communication Technologies and Their Impact in the Economic Growth of Latin America, 1990-2013. Telecommunications Policy, vol. 40, no 5, pp. 485-501. Available at: https://doi.org/10.1016/j.telpol.2016.02.002.

Ignatov A.A. (2020) The Digital Economy of BRICS: Prospects for Multilateral Cooperation. International Organisations Research Journal, vol. 15, no 1, pp. 31-62. Available at: https://doi.org/10.17323/1996-78452020-01-02.

Inclusive Internet Index. (2020) Available at: https://theinclusiveinternet.eiu.com/explore/countries/performance (accessed 4 November 2020).

Independent Communications Authority of South Africa (ICASA). (2019) State of the ICT Sector in South Africa: 2019 Report. Available at: https://www.icasa.org.za/legislation-and-regulations/state-of-ict-sector-insouth-africa-2019-report (accessed 4 November 2020).

International Telecommunication Union (ITU). (2019) Economic Contribution of Broadband, Digitization and ICT Regulation: Econometric Modelling for Africa. Available at: https://www.itu.int/dms_pub/itu-d/opb/pref/ D-PREF-EF.BDT_AFR-2019-PDF-E.pdf (accessed 25 March 2020).

International Telecommunication Union (ITU) (n. d) Statistics. Available at: https://www.itu.int/en/ITU-D/ Statistics/Pages/stat/default.aspx (accessed 4 November 2020).

Jung J., Lopez-Bazo E. (2020) On the Regional Impact of Broadband on Productivity: The Case of Brazil. Telecommunications Policy, vol. 44, no 1, pp. 1-14. Available at: https://doi.org/10.1016/j.telpol.2019.05.002.

Katz R., Callorda F. (2018) The Economic Contribution of Broadband, Digitization and ICT Regulation. Expert Reports, International Telecommunication Union. Available at: https://www.itu.int/en/ITU-D/Regulatory-Market/Documents/FINAL_1d_18-00513_Broadband-and-Digital-Transformation-E.pdf (accessed 25 March 2020).

Liu C., Wang L. (2019) Does National Broadband Plan Narrow Regional Digital Divide? Evidence from China. Chinese Journal of Communication, vol. 12, no 4, pp. 449-66. Available at: http://doi.org/10.1080/1754475 0.2019 .1609539 . 
Lucendo-Monedero A.L., Ruiz-Rodriguez F., Gonzalez-Relano R. (2019) Measuring the Digital Divide at Regional Level: A Spatial Analysis of the Inequalities in Digital Development of Households and Individuals in Europe. Telematics and Informatics, vol. 41, pp. 197-217. Available at: https://doi.org/10.1016/j. tele.2019.05.002.

Luk'yanova A.L. (2007) Dinamika i struktura neravenstva po zarabotnoj plate (1998-2005) [Dynamics and Structure of Inequality in Wages (1998-2005)]. Working Paper WP3/2007/06. Moscow: HSE (in Russian). Available at: https://www.hse.ru/data/2010/05/04/1216406894/WP3_2007_06.pdf

Ministry of Digital Development, Communications and Mass Media of the Russian Federation (n. d.) Statistics. Available at: https://digital.gov.ru/ru/activity/statistic/ (accessed 4 November 2020) (in Russian).

National Bureau of Statistics of China. (n. d.) Annual Data. Available at: http://www.stats.gov.cn/english/Statisticaldata/AnnualData/ (accessed 4 November 2020).

New Development Bank (NDB). (n. d., a) Pará Sustainable Municipalities Project. Available at: https://www. ndb.int/projects-parabrazil/ (accessed 4 November 2020).

New Development Bank (NDB). (n. d., b) Zhejiang Green Urban Project: Shengzhou Urban and Rural Integrated Water Supply and Sanitation Project. Available at: https://www.ndb.int/zhejiang-green-urban-projectshengzhou-urban-and-rural-integrated-water-supply-and-sanitation-project-phase-ii/ (accessed 4 November 2020).

Niebel T. (2014) ICT and Economic Growth Comparing Developing, Emerging and Developed Countries. ZEW Centre for European Economic Research Discussion Paper No 14-117. Available at: https://doi.org/10.2139/ ssrn.2560771.

Norris P. (2001) Digital Divide: Civic Engagement, Information Poverty, and the Internet Worldwide. Cambridge University Press.

Organisation for Economic Co-operation and Development (OECD). (2001) Understanding of the Digital Divide. Available at: https://www.oecd.org/sti/1888451.pdf (accessed 4 November 2020).

Perfil'eva O.V. (2007) Problema cifrovogo razryva i mezhdunarodnye iniciativy po ee preodoleniyu [Getting Over Digital Divide and International Initiatives]. Vestnik mezhdunarodnykh organizatsiy [International Organisations Research Journal], vol. 2, no 2, pp. 34-48. Available at: https://iorj.hse.ru/data/2011/02/03/1208841767/ getting_over_digital.pdf (accessed 4 November 2020) (in Russian).

Sidorova E. (2018) The Innovation Development of the BRICS Countries: Preconditions and Prospects for Cooperation. International Organisations Research Journal, vol. 13, no 1, pp. 34-50. Available at: https://doi. org/10.17323/1996-7845-2018-01-02.

Sokolov A., Shashnov S., Kotsemir M., Grebenyuk A. (2017) Identification of Priorities for S\&T Cooperation of BRICS Countries. International Organisations Research Journal, vol. 12, no 4, pp. 32-67. Available at: http:// doi.org/10.17323/1996-7845-2017-04-32.

Song Z., Wang C., Bergmann L. (2020) China's Prefectural Digital Divide: Spatial Analysis and Multivariate Determinants of ICT Diffusion. International Journal of Information Management, vol. 52, pp. 1-12. Available at: https://doi.org/10.1016/j.ijinfomgt.2020.102072.

Tkachenko I.Yu. (2018) Perspektivy sotrudnichestva stran BRIKS v razvitii cifrovoj ekonomiki [Perspectives of BRICS Cooperation in Development of Digital Economy]. Bol'shaya Evraziya: Razvitie, bezopasnost', sotrudnichestvo [Great Eurasia: Development, Security, Cooperation], vol. 1, part 1, pp. 339-43. Available at: http:// inion.ru/site/assets/files/2409/bol_shaia_evraziia_2018_1_1.pdf (accessed 25 March 2020) (in Russian).

Torgovo-Promyshlennaya Palata Rossijskoj Federacii (TPP RF). (2019) Ukreplenie sotrudnichestva $v$ cifrovoj ekonomika dolzhno stat' prioritetnym [Strengthening Cooperation in the Digital Economy Sphere Should Be a Priority]. 9 April. Available at: https://tpprf.ru/ru/mobile/news/ukreplenie-sotrudnichestva-v-tsifrovoyekonomike-dolzhno-stat-prioritetnym-schitayut-v-rossiyskoy-ch-i299867/ (accessed 28 May 2020) (in Russian).

United Nations (UN). (2018) UN E-Government Survey. Department of Economic and Social Affairs. Available at: https://www.un.org/development/desa/publications/2018-un-e-government-survey.html (accessed 25 March 2020). 
United Nations Conference on Trade and Development (UNCTAD). (2019) Value Creation and Capture: Implications for Developing Countries. Digital Economy Report 2019. Available at: https://unctad.org/system/files/ official-document/der2019_en.pdf (accessed 4 November 2020).

United Nations Educational, Scientific and Cultural Organization Institute for Statistics (UNESCO UIS). (n. d.) Available at: https://www.itu.int/en/ITU-D/Statistics/Pages/stat/default.aspx (accessed 4 November 2020).

World Bank. (2016) World Development Report: Digital Dividends. Available at: https://www.worldbank.org/en/ publication/wdr2016 (accessed 4 November 2020).

World Economic Forum (WEF). (2019) The Global Competitiveness Report 2019. Available at: http://reports. weforum.org/global-competitiveness-report-2019/downloads/ (accessed 25 March 2020). 